\title{
La dimensió cultural de la universitat espanyola. Estat de la qüestió
}

\author{
Antonio Javier González Rueda \\ UNIVERSIDAD DE CADIZ \\ antonio.gonzalez/uuca.es \\ Antonio Ariño Villarroya \\ UNIVERSITAT DE VALÈNCIA \\ antonio.arinoluuv.es
}

Rebut: 10/06/2019

Acceptat: 27/03/2020

\section{RESUM}

La dimensió cultural de la universitat espanyola és una realitat històrica que ha anat evolucionant, sobretot des de l'arribada de la democràcia a Espanya. Aquesta investigació planteja una reflexió terminològica i n'exposa l'evolució històrica en una anàlisi comparada de la situació mundial, al mateix temps que estableix un diagnòstic del moment actual a partir de dos treballs de camp complementaris que permeten traure a la llum els principals problemes i barreres del que, fins fa poc, es considerava el tercer principi de la universitat després de la docència i la investigació.

Paraules clau: gestió cultural universitària, extensió universitària, missions de la universitat, sociologia de la cultura, estudis culturals.

ABSTRACT. The Cultural Dimension of Spanish Universities: The state of the issue

The cultural dimension of Spanish universities has changed markedly, especially since the restoration of democracy in Spain in the late 1970s. This study reflects on the terminology and the historical evolution of Spanish universities, comparing their development within a broader world context. It also analyses the present state of affairs through two complementary pieces of field work. The paper concludes by examining the issues and hurdles that until recently were the third dimension of university life after teaching and research.

Keywords: university cultural management, university extension, university missions, sociology of culture, cultural studies.

\section{SUMARI}

El terme Dimensió cultural de la universitat

Breu revisió històrica

Diagnòstic de la dimensió cultural en l'actualitat

Conclusions

Coda

Referències bibliogràfiques 
Autor per a correspondència / Corresponding author: Antonio J. González Rueda. Comisionado para el Plan Estratégico de la Universidad de Cádiz. Vicerrectorado de Política Educativa. Centro Cultural Reina Sofía. Sede del Rectorado de la Universidad de Cádiz. Paseo Carlos III, 9. 11.003- Cádiz (Espanya).

Suggeriment de citació / Suggested citation: González Rueda, A. J. i Ariño Villarroya, A. (2020). La dimensió cultural de la universitat espanyola. Estat de la qüestió. Debats. Revista de cultura, poder i societat, 134(1), 217-232. DOI: http://doi.org/10.28939/iam.debats.134-1.13

La cultura és un bé de primera necessitat. Contribueix al benestar de les persones, en la mesura que les dota de més instruments per a l'aventura humana. És un factor de complicació, que enriqueix l'experiència, un moment que, des de Montaigne, sabem que ens constitueix com a persones, però la cultura no és garantia de res: ni de bé, ni de veritat, ni de felicitat, ni d'èxit

(Ramoneda, 2013).

\section{EL TERME DIMENSIÓ CULTURAL DE LA UNIVERSITAT}

El ja llunyà 2012, proposàvem a la comunitat acadèmica, a la comunitat professional de la gestió cultural i a la societat en general el terme dimensió cultural de la universitat com a terme paraigua per a descriure totes aquelles tasques que la universitat emprén en matèria de cultura universitària $\mathrm{i}$ altres disciplines relacionades (Ariño Villarroya i González Rueda, 2012). Tot i que el terme no ha prosperat en els àmbits professionals i socials en què intervé la universitat, sí que ha tingut cert ressò en l'àmbit acadèmic (Penelas, 2013) i en els mitjans de comunicació (Mejía Arango, 2018).

Evidentment, la proposta epistemològica de l'ús de la dimensió cultural (d'ara endavant, DC) és difícilment traslladable als àmbits de la gestió o de l'activitat universitària, ja que ens trobem davant d'una categorització que intenta integrar realitats molt diferents sota un concepte general (dimensió) que es qualifica i es concreta per mitjà de l'adjectiu cultural. No es tractava, per tant, de proposar una marca distintiva sinó de dotar aquesta dimensió de l'activitat universitària d'un paradigma que la definira en règim d'equitat amb la dimensió docent i la dimensió investigadora de la institució universitària.

La DC és, d'altra banda, l'element que permet donar coherència a una trajectòria històrica que s'estén al llarg de quasi 150 anys, des de la vetusta extensió universitària datada a Cambridge el 1871 (Palacios Morini, 1908: 126) fins a la responsabilitat social més recent (Ruiz, 2016). A més, és un terme que integra la legitimitat històrica i la legitimitat normativa de la funció cultural de la universitat (Ariño Villarroya, 2007). Des de la seua protohistòria, la cultura apareix com un element central de les funcions i missions de la universitat. No obstant això, hi ha una dificultat notòria en la definició i ubicació d'aquesta dimensió que pot explicar-se per raons d'índole diversa:

- L'extensió universitària es va pensar originàriament com una missió ad extra en un moment en què les comunitats universitàries eren —en comparació amb les actuals- molt menudes. Quan les comunitats universitàries adquireixen 
una grandària considerable, els membres de la pròpia comunitat són, en paraules de Rowan, creadors i consumidors de béns i serveis culturals al mateix temps (García, 2019).

- Tradicionalment, en l'àmbit de la universitat s'han produït dues confusions sobre la cultura: una tendeix a identificar el coneixement amb la cultura; l'altra identifica la cultura amb les arts i les humanitats. Per tant, si la cultura és equivalent al coneixement, es concep la universitat com una institució cultural en si mateixa, en la qual tots els actors i les funcions són culturals pel simple fet d'existir; en canvi, si és equivalent a les arts, es considera que constitueix només una part de l'activitat universitària. (González Rueda, 2004: 181)

- L'extensió universitària com a experiència pedagògica ens va deixar il-lustres promotors: Clarín, Aniceto Sela, Paulo Freire, etc. Orgullosos dels seus antecedents, els espectres del passat de vegades actuen com a fre per a entendre el present de la DC.

- A diferència d'Espanya, en l'esfera anglosaxona la DC s'ha desenvolupat com un complement curricular i vivencial dels estudiants des de les estructures descentralitzades de les facultats i escoles. Per exemple, la Universitat de Harvard compta, en l'actualitat, amb una Escola d'Educació Contínua en la Facultat d'Arts i Ciències, que inclou l'Escola d'Estiu de Harvard i l'Escola d'Extensió Universitària de Harvard. ${ }^{1}$

- Als Estats Units i Anglaterra, els clubs temàtics protagonitzen part de la DC amb un ampli suport per part dels estudiants.
1 Harvard University. Web Online and On-Campus Courses Harvard Extension School. Recuperat el 6 d'abril de 2019 de https://www.extension.harvard.edu/academics/onlinecampus-courses.

\section{BREU REVISIÓ HISTÒRICA}

Ja que fem referència a l'extensió universitària (un dels eixos històrics de la DC), a continuació en recordem les principals fites, les actualitzem i les referenciem.

El concepte històric d'extensió universitària és quasi tan antic — almenys pel que fa als antecedents_ com la mateixa universitat, ja que es produeixen intents primerencs per part de professors universitaris d'impulsar l'anomenada educació popular. Com a exemples d'aquestes iniciatives inaugurals, podem esmentar les conferències del financer Thomas Gresham a comerciants i artesans en el Londres del segle xvı o les iniciatives de William Dills al Col-legi de Cains a Cambridge el 1630 (Melón Fernández, Álvarez Antuña, Friera Suárez i Ruiz de la Peña, 2002: 130). No obstant això, fins al 1871 -en el context del convuls i reivindicatiu segle XIX amb la qüestió social emergint- no es crea l'extensió universitària de Cambridge (Palacios Morini, 1908: 126) amb cert caràcter oficial. Tot seguit, Oxford i altres universitats fan el mateix. Als Estats Units, l'any 1890 es publica el University Extension Journal (Welch, 1973: 201) i es funda la Philadelphia American Society For Extension of University.

Draper exposa la gènesi de l'extensió universitària produïda a Cambridge - $\mathrm{i}$ a altres llocs - en conferències divulgatives per a dones, que després s'amplien a homes a petició popular:

En aquest instructiu llibret, el mestre del temple explica amb claredat l'origen i el desenvolupament d'un moviment molt destacat que ha beneficiat tant les universitats com les masses. Cambridge va obrir el camí, a instàncies del professor James Stuart, que va començar fent classe a dones l'any 1867 , i prompte es va adonar que els homes estaven igual d'ansiosos per assistir a xerrades de divulgació sobre temes importants. Oxford s'hi va afegir el 1878 i, des d'aleshores, Londres, Manchester i les universitats més joves n'han seguit l'exemple. (Draper, 1923)

Després d'Anglaterra, Alemanya va tindre una important labor divulgativa als grans centres industrials. 
No obstant això, a França la idea subjacent en l'extensió universitària queda oculta per l'eclosió de les universitats populars, que sorgeixen al marge de la universitat. A Espanya, tot i que hi hagué alguns precedents interessants anteriors a la Universitat de Saragossa, el naixement oficial de l'extensió universitària se situa a la Universitat d'Oviedo l'11 d'octubre de 1898. Potser és més oportú recórrer a les paraules del catedràtic Aniceto Sela, que actua com a fedatari del moment:

En la sessió del Claustre de Professors de l'11 d'octubre de 1898, el senyor Leopoldo Alas recollint importants consideracions de la lliçó inaugural d'aquest curs, llegida pel Senyor Altamira, i tenint en compte els treballs que, a tot arreu, fora d'Espanya, es fan a favor de la cultura popular, proposa al Claustre de la Universitat d'Oviedo que emprenga, des d'ara, l'obra utilíssima denominada Extensió Universitària. (Coronas, 2005)

El mateix Sela recordava que «les nostres universitats necessiten més que d'altres baixar al poble, educar-lo, col-laborar amb la gran obra de l'educació nacional d'una manera més activa i de resultats més immediats que els que poden esperar-se del cultiu de la ciència pura, que n'és la fi principal». L'idealisme i una certa ingenuïtat dels impulsors de l'extensió universitària espanyola degué portar els seus detractors a titllar-la de «sectària i proselitista, republicana, anticlerical i socialistoide, hipòcrita, pedant i inútil» (Melón Fernández, 1987: 105).

Encara que l'objecte d'aquest article no és mostrar la trajectòria històrica de la DC - tema apassionant, per cert, i que requeriria investigacions més rigoroses de les fonts originals ${ }^{2}$-, podem concloure que, amb caràcter general, el moviment sociopedagògic de l'extensió universitària va ser, des del nostre punt de vista, un dels molts efectes de l'expansió dels ideals de la revolució francesa. L'extensió universitària i les

2 Recomanaria per la seua riquesa de detalls el capítol sobre l'extensió universitària que recull Leopoldo Palacios Morini en la seua obra sobre les universitats populars (Palacios Morini, 1908). universitats populars van caminar juntes, però per camins bifurcats, ja que la primera sol identificar-se amb el reformisme, mentre que les universitats populars, amb la ruptura; encara que totes dues van tractar de respondre al mateix problema social apressant.

A Amèrica Llatina -històricament i també en l'actualitat- l'extensió universitària és considerada la tercera funció o missió de la universitat (docència, investigació i extensió), i és la que s'incorpora més tardanament de les tres. Com en el cas espanyol, és més un enfocament (un corrent de pedagogia universitària) que una funció, a diferència del model històric europeu, es desplega no només en la universitat sinó també en l'àmbit sanitari i rural. Com a mostra, podem citar Paulo Freire, que el 1961 va ser nomenat director del Departament d'Extensió Cultural de la Universitat de Recife. Arran d'aquest nomenament, va tindre l'oportunitat d'aplicar de manera significativa les seues teories pedagògiques. Entre altres assoliments, va ensenyar a llegir i escriure a tres-cents treballadors de cultius de canya de sucre en tan sols 45 dies (Freire, 1973). Els vectors en què es mou l'extensió universitària llatinoamericana són saber-coneixement, professionals-tècnics, dins-fora. Com a Espanya, la pràctica ha tensionat la teoria, i això ha derivat, segons el nostre punt de vista, en el fet que no haja sigut possible construir un concepte compartit d'extensió universitària, tampoc a Amèrica Llatina.

Durant tota l'expansió de l'extensió universitària per Europa i Llatinoamèrica preval la convicció emancipadora de la cultura i la voluntat de transmetre-la des de la universitat, que és l'origen de l'actual funció social d'aquesta institució. Després del seu naixement $\mathrm{i}$ assentament, durant la segona meitat del segle $\mathrm{xx}$, el moviment es desenvolupa de diferents maneres en funció del país, tot i que en general preval una certa normalització i institucionalització de les activitats de la DC en el context d'unes universitats cada vegada més grans i amb més cobertura social.

Si ens centrem en el cas espanyol, l'escassa literatura existent va promoure la idea que l'extensió universitària va llanguir sota l'opressió franquista. Tot i 
que, en part, pot ser que fora així, les investigacions parcials de Cantero (2006) han demostrat que aquest període va ser més actiu i interessant del que es pensava. No obstant això, és cert que l'eclosió de la DC a Espanya es produeix amb l'aprovació de la Llei orgànica 11/1983 de reforma universitària, que en l'article primer, apartat $2 \mathrm{~d}$, recull aquesta dimensió i la legitima amb la creació de vicerectorats d'extensió universitària, extensió cultural o activitats culturals, que no fan més que desplegar alguns principis d'aquesta llei.

Aquesta legitimació normativa es reforça, l'any 2007, amb l'aprovació de la Llei orgànica 4/2007 (LOMLOU), per mitjà de la qual es modifica la Llei orgànica d'universitats aprovada l'any 2001, que recull «la difusió del coneixement i la cultura a través de l'extensió universitària i la formació al llarg de tota la vida» (art. 1) com una funció de la universitat i integra en la funció docent la idea que «les ensenyances per a l'exercici de professions que requereixen coneixements científics, tècnics o artístics, i la transmissió de la cultura són missions essencials de la Universitat» (art. 33). Finalment, s'hi dedica un article complet a la cultura universitària (art. 93):

És responsabilitat de la universitat connectar l'universitari amb el sistema d'idees vives del seu temps. Amb aquesta finalitat, les universitats han d'arbitrar els mitjans necessaris per potenciar el seu compromís amb la reflexió intel-lectual, la creació i la difusió de la cultura. Específicament les universitats han de promoure l'apropament de les cultures humanística i científica i s'han d'esforçar per transmetre el coneixement a la societat mitjançant la divulgació de la ciència.

Addicionalment, la LOMLOU esmenta també, en l'article 46, «el reconeixement acadèmic per (...) activitats culturals, (...)» o l'existència $\mathrm{d}^{\prime}$ «estudiants no tradicionals» (art. 42). Quan la norma es refereix als estatuts respectius de cada universitat, es detecta una certa repetició dels principis de la LOMLOU de vegades de forma literal- i també la inclusió de conceptes com cultura universitària, extensió o activitats culturals en diversos apartats d'aquests estatuts, però sempre en un pla missional més que de desen- volupament normatiu. En aquest sentit, pot semblar que la DC és més de preàmbuls que d'articulats.

La inherent necessitat de reconeixement intern i extern va portar les universitats espanyoles a dur a terme, després de la posada en marxa de la LRU, diversos intents de coordinació i de treball en xarxa. En general, s'ha intentat copiar — sense èxit- el model d'altres dimensions universitàries que compten amb una sectorial específica en el marc del Consell de Rectors de les Universitats Espanyoles (d'ara endavant, CRUE) ${ }^{3}$. Aquests intents, sense ànim de ser exhaustius, es podrien resumir en els següents:

- El febrer de 1991, vicerectors de la majoria d'universitats públiques es reuneixen a la Universitat de La Laguna. En aquesta reunió es reconeix la necessitat de constituir equips tècnics professionalitzats per a dotar els vicerectorats respectius de recursos de gestió estables (Sol-licitud de creació de la comissió sectorial d'extensió universitària al si de la CRUE, 2003).

- Entre 1991 i 1992 es crea un grup informal de coordinació d'extensió universitària i s'inicien els contactes amb la CRUE per constituir-se com a sectorial, alhora que s'estableix comunicació amb el Ministeri de Cultura i amb algunes conselleries autonòmiques amb la finalitat de determinar canals de col·laboració institucional conjunta.

- Els anys 1992 i 1993 es reuneixen els plenaris de vicerectors d'extensió universitària en diverses ocasions (Còrdova, Alacant, Balears) que culminen en les Jornades de Gestió Universitària a Barcelona, celebrades el mes de novembre de 1993.

- El 1998 tenen lloc altres dues cites: a València i a Oviedo. A València s'aborda una reflexió sobre la realitat de la cultura universitària en el llindar del segle xxI. Aquesta reunió serveix com a preludi per al Congrés Internacional Iberoamericà celebrat a Oviedo amb motiu de la commemoració del

3 Conferència de Rectors de las Universitats Espanyoles, CRUE - Sectorials. Recuperat el 28 de març de 2019 de http://www.crue.org/SitePages/Sectoriales.aspx. 
centenari de l'extensió universitària. Curiosament, en aquest congrés no es van redactar les actes habituals, la qual cosa va comportar una pèrdua d'informació evident (García Guatas, 2004). En tots dos casos es planteja de nou la necessitat de constituir una sectorial pròpia.

- L'any 2002, en ocasió del Congrés Internacional sobre Rafael Altamira (Alacant), es redacta la Declaració de Biar sobre Extensió Universitària, document que es presenta a la CRUE amb escassos resultats.

- El 2017, en el marc del Seminari dels Cursos d'Estiu de Cadis, es promou el curs Universitat i cultura: balanç d'una relació (González Rueda, 2017), del qual sorgeix la denominada Declaració de Cadis, que proposa la creació d'un grup de treball emparat per la CRUE (Parodi Álvarez, 2017).

En l'àmbit autonòmic, l'experiència de coordinació amb millors resultats i la trajectòria temporal més gran és la corresponent a la Sectorial d'Extensió Universitària del Consell Andalús d'Universitats, de la qual sorgeix l'any 2006 el Proyecto Atalaya, que integra les deu universitats andaluses i en el qual destaca, com a bona pràctica, l'Observatorio Cultural del Proyecto Atalaya, promogut per la Universitat de Cadis i la Internacional d'Andalusia (Red Telescopi).

Finalment, fem un repàs de l'àmbit internacional. En l'espai anglosaxó, el terme university extension es manté i té un ús comú i socialitzat, com ho demostra el fet que disposa d'una entrada pròpia en l'Enciclopèdia Britànica (Encyclopedia Britannica). En aquest context, l'extensió universitària és una divisió de l'educació superior destinada a les persones que no són estudiants a temps complet. Així doncs, conté activitats a distància, formació contínua o educació universitària d'adults. S'hi atribueix haver contribuït a la integració de les dones en l'educació superior:

Extensió universitària: departament d'una institució d'ensenyament superior que duu a terme activitats educatives per a persones (normalment adultes) que generalment no són estudiants a temps complet.
A vegades, aquestes activitats es denominen estudis extraacadèmics, educació contínua, educació superior per a adults o educació universitària per a adults. Des de la seua creació, la formació de grups mitjançant classes formals, grups de debat, seminaris i tallers ha continuat sent el nucli dels cursos d'extensió. Una conseqüència important del moviment d'extensió va ser que va contribuir a l'accés de les dones a l'educació superior.

El 1867, un professor de la Universitat de Cambridge va oferir un curs d'extensió, i la dècada de 1880 , aquests cursos van començar a florir a centres de tota Anglaterra. Al voltant de 1885, dirigents universitaris dels Estats Units van conéixer els programes de les universitats britàniques. L'efecte més significatiu es va produir en la Universitat de Chicago quan l'extensió es va incloure com a part integral del disseny de la nova universitat i es van proveir fons per als centres situats fora del campus, la formació per correu i altres programes.

En moltes universitats dels Estats Units el nombre de persones adultes que participa en programes d'extensió ha arribat a ser superior al d'estudiants matriculats a temps complet a les facultats, i les unitats especialitzades que ofereixen aquests programes han proliferat ràpidament. Algunes universitats es van reorganitzar per a donar més importancia a l'extensió com a funció institucional paral-lela a les docència i investigació.

En termes generals, es pot dir que on més plenament s'ha desenvolupat l'extensió universitària ha sigut als països de parla anglesa. En alguns casos, seguint l'exemple britànic, s'empra el terme estudis extraacadèmics (extramural studies).

\section{DIAGNÒSTIC DE LA DIMENSIÓ CULTURAL EN L'ACTUALITAT}

Fins ací hem repassat els aspectes històric, normatiu i operatiu de la DC, amb especial atenció al cas espanyol. Un dels problemes que emergeixen després d'aquesta revisió és la falta de centralitat i de 
reconeixement intern de la DC. Aquesta barrera està especialment present en l'apartat de les taules de classificació i els premis nacionals i internacionals. Els principals rànquings mundials globals contemplen la dimensió investigadora i de transferència (en tots els casos) i la docent-acadèmica (en alguns), però no apareix cap indicador relacionat amb la dimensió cultural. En un pla molt secundari, es detecta en algun indicador concret una connexió ínfima amb el tema de la propietat intel-lectual i les patents. Només el rànquing $\mathrm{CyD}$ (Fundación Conocimiento y Desarrollo) inclou, en l'àmbit de la investigació, l'indicador Producció artística ${ }^{4}$. Així mateix, l'informe de la CRUE Universitat en Xifres conté una breu bateria d'indicadors de cultura universitària. Els intents realitzats per la Universitat de València per a proposar un indicador de la DC en U-Ranking BBVA no han arribat a bon port. En el cas dels reconeixements externs o premis, un bon baròmetre de la invisibilitat de la DC s'obté repassant les bones pràctiques seleccionades per la Xarxa Telescopi, on només hi apareixen, en relació amb la DC, dues bones pràctiques de la Universitat de Cadis: Observatorio Atalaya i Herramienta Celama (Red Telescopi).

De manera complementària, una de les formes transversals d'analitzar el grau d'acceptació del terme dimensió cultural de la universitat és observar la presència d'allò cultural (cultura, cultural) en les denominacions dels vicerectorats espanyols encarregats de la cultura universitària, ja siga directament o indirectament. Per a això, amb motiu d'una ponència en el curs d'estiu Cultura en / des de / per a la Universitat (2018) vam dur a terme novament l'exercici d'estudiar les denominacions dels vicerectorats relacionats amb la dimensió cultural mitjançant una cerca detallada en les pàgines web institucionals de les 76 universitats públiques i privades relacionades en la pàgina web

4 Nombre de resultats artístics basats en arts creatives escèniques, dividit per PDI (ETC).

5 Cultura en/desde/para la Universidad. (2018). Recuperat el 28 de marc de 2019 de https://www.uik.eus/es/culturaendesdepara-la-universidad de la CRUE ${ }^{6}$. L'anàlisi ${ }^{7}$ es va fonamentar en la cerca del vicerectorat en qüestió de cada universitat, l'extracció de descriptors i l'anàlisi de repeticions, i queda expressat en la figura de núvol d'etiquetes (Figura 1).

\section{Figura 1 Núvol d'etiquetes després de l'anàlisi}

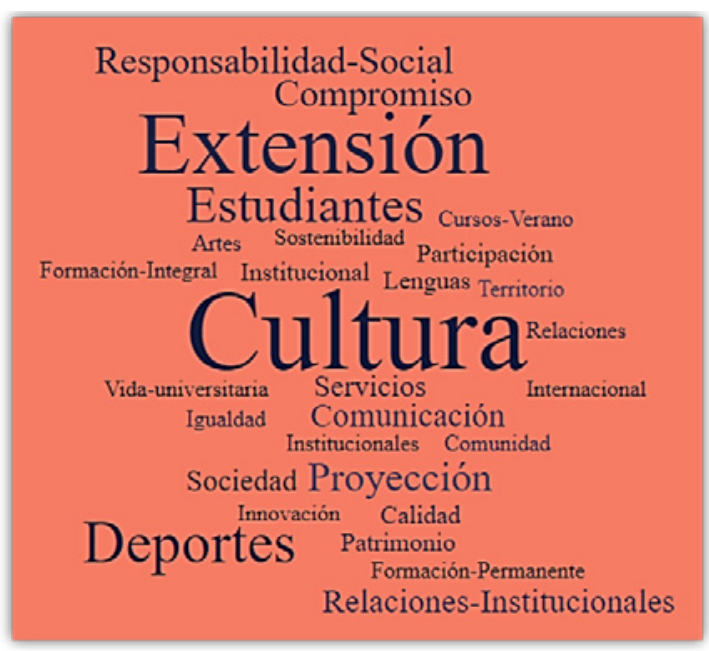

Font: Elaboració pròpia.

Com reflecteix gràficament la Figura 1, el descriptor amb més aparicions és cultura (26), seguit d'extensió (19) i esports (11). A continuació, matisem aquesta presència aclaparadora d'allò cultural mitjançant el seu terme més directe (cultura) i el menys directe (extensió), que a Espanya s'associa històricament a la cultura universitària i la seua difusió.

1. De les 26 universitats privades, 20 no compten amb un vicerectorat que incloga expressament la dimensió cultural.

2. Amb el pas dels anys, la dimensió cultural apareix cada vegada més com a companya de viatge

6 Conferència de Rectors de les Universitats Espanyoles Recuperat el 28 de març de 2019 de http://www.crue.org/ universidades/SitePages/Universidades.aspx.

7 Anàlisi realitzada mitjançant l'accés a pàgines institucionals el dia 4 de juliol de 2018 
d'altres subfuncions (esports, projecció social, comunicació o qualitat).

3. De 55 universitats que inclouen la dimensió cultural en l'estructura, 53 mantenen el nivell de vicerectorat.

4. Augmenta el nombre d'universitats que inclouen la dimensió cultural en vicerectorats òmnibus en els quals allò cultural es dilueix o queda com a element secundari (estudiants, projecció, responsabilitat, etc.).

Tot i que la categorització dimensió cultural pot continuar sent útil per a integrar coherentment totes aquestes realitats des d'un punt de vista científic, segueix sent difícil trobar una marca comuna que identifique la dimensió cultural des del punt de vista orgànic o funcional de les estructures universitàries. $\mathrm{Al}$ nostre parer, entitats com el Vicerectorat de Cultura Universitària o el Vicerectorat d'Extensió Cultural poden ser dos bons punts de partida per a la construcció d'una marca comuna de la dimensió cultural de les universitats espanyoles. La primera connectaria millor amb les universitats amb menor tradició en matèria cultural, i la segona integraria bé la trajectòria històrica d'universitats que quasi des de principis del segle xx van intentar desenvolupar la missió cultural de la universitat. A més, recull en el seu enunciat el terme cultura universitària que, per a Ariño, seria una cultura amb les següents característiques:

Científica: una cultura del logos enfront del prejudici; de l'evidència i l'argumentació; en última instància, sotmesa al mètode.

Crítica: una cultura que es basa en la millor tradició de la sospita, de la posada en qüestió de les visions hegemòniques que legitimen relacions de poder.

Creativa i innovadora: en el sentit que promou la novetat rellevant per a millorar la dignitat i la qualitat de la vida humana.
Acadèmica: «que opera en el nivell de síntesi, d'interrelació i de coordinació de sabers en una era en què els problemes són globals i transfronterers» (Ariño Villarroya, 2016).

Paral-lelament a aquesta anàlisi que ja hem mostrat i partint d'un autodiagnòstic que vam proposar en el curs d'estiu de la Universitat del País Basc (Cultura en / des de / per a la Universitat, 2018) albirem la necessitat de sotmetre aquest autodiagnòstic a un procés de validació per part de parells o experts; en aquest cas, dels responsables acadèmics i professionals dels vicerectorats de la dimensió cultural de les universitats espanyoles.

A partir del treball de camp anterior sobre les denominacions de vicerectorats, vam seleccionar 41 universitats (39 públiques i 2 privades) que tenien alguna trajectòria en aquest àmbit $i$ disposaven en les seues pàgines web d'adreces electròniques dels responsables acadèmics o tècnics. Es van realitzar 81 invitacions a correus individuals, en els quals se'ls convidava, mitjançant una enquesta generada des de la plataforma LimeSurvey ${ }^{8}$ de la Universitat de Cadis, a validar l'esmentat diagnòstic de la dimensió cultural. Se'n van rebre 51 enquestes completes, la qual cosa suposa un percentatge de resposta del $63 \%$. Dels que van completar l'enquesta, el $69 \%$ pertanyien a l'estament del personal d'administració i serveis (d'ara endavant, PAS) i el $31 \%$, a personal docent i investigador (d'ara endavant, PDI), cosa que és coherent amb un major nombre d'efectius en l'aparell tècnic $i$ administratiu respecte del directiu. Des del punt de vista del gènere, el $53 \%$ eren homes i el $47 \%$, dones. Vegem, a continuació, en quin grau va ser recolzat l'autodiagnòstic que se'ls plantejava, format per 24 hipòtesis, sobre la dimensió cultural de la universitat:

1. La dimensió cultural de la Universitat posseeix objectius difusos i poc delimitats per part de la institució. El $57 \%$ dels enquestats recolza que la DC no compta amb objectius ben

8 Les enquestes van ser completades en el període comprés entre l' 1 i el 20 de juny de 2018. 
delimitats per part de la institució, i si existeixen, són vagues. Potser és aquest un dels motius - estar fora del focus- pels quals aquests vicerectorats tenen més llibertat de moviment $\mathrm{i}$ menys control que les altres dues missions de la universitat. Des del nostre punt de vista, la DC no disposa d'una missió expressada i acceptada. A diferència d'Amèrica Llatina, ací la DC no apareix integrada ni en un percentatge menut en la docència i la investigació. A Llatinoamèrica, confusament, «constitueix una de les funcions essencials de la universitat i és síntesi de la resta de les seues funcions per a la consecució de la seua pertinència social; per tant, integra la docència i la investigació» (Cedeño Ferrín, 2012). En aquest sentit, al nostre parer, s'assemblaria bastant al nostre concepte de transferència, però amb una vocació social i de desenvolupament comunitari.

2. La DC integra tal quantitat de subdimensions que es fa difícil establir la seua missió. El $61 \%$ dels enquestats està d'acord amb aquest aspecte del diagnòstic. La DC, com ja hem comentat, integra tantes subdimensions de diversos estadis que és quasi impossible establir quina missió té: activitat esportiva, divulgació de la ciència, editorials universitàries, universitats d'estiu, aules de majors, museus, patrimoni, etc. Sembla, doncs, que tenim un clar problema missional.

3. La DC és perifèrica a l'acció de govern de la universitat. El $71 \%$ - especialment, el personal de gestió- recolza aquesta afirmació. La DC és perifèrica en l'acció de govern de la universitat, la qual cosa — com ja hem comentat— té avantatges (llibertat de moviment), però, sobretot, desavantatges (falta de centralitat de la DC).

4. La DC de la universitat està protagonitzada per més agents col-lectius i individuals que els vicerectorats de la dimensió cultural (centres, departaments, instituts d'investiga- ció, col-legis majors, càtedres, associacions, professorat, etc.). Aquests agents col-laboren i, alhora, competeixen amb els vicerectorats específics de cada universitat. De nou, el $71 \%$ comparteix que la DC no només juga en el terreny dels vicerectorats del ram, sinó que hi ha actors col-lectius (centres, departaments, instituts, col-legis majors, etc.) i individuals que col-laboren, concorren o competeixen. En resum, aquests vicerectorats només gestionen una part de la DC de la institució.

5. Els recursos humans de la DC han millorat en quantitat i qualificació respecte de la dècada dels 90 , tot i que presenten un envelliment progressiu que dificulta el relleu generacional dels professionals. No hi ha un acord clar amb aquesta afirmació (el $51 \%$ hi està d'acord), encara que el suport sí que és superior entre el PAS. Potser, un cert desconeixement del seu caràcter buit en les dècades dels 80 i 90 justifica aquest suport tebi.

6. Les infraestructures i els equipaments culturals universitaris són millors que fa uns anys, però depenen molt dels recursos econòmics per al seu manteniment i activitat. El 92 \% està d'acord que la DC ha millorat en recursos humans i materials, però no en recursos econòmics. Estem davant d'unitats organitzatives que caminen amb peus de fang, especialment després de la prolongada crisi financera que arrosseguem des de 2009.

7. Els vicerectorats de la DC comparen escassament les seues programacions i projectes amb els programes que realitzen altres universitats espanyoles $i$, especialment, amb els realitzats per universitats europees. El $84 \%$ dels enquestats subscriu el diagnòstic, tot i que amb menor suport per part de les persones enquestades que ocupen càrrecs acadèmics.

8. Els programes culturals i creatius proposats 
pels vicerectorats de la DC són discontinus en el temps. Aquest ítem del diagnòstic no rep prou suport per a donar-lo per vàlid (el 51 \% hi està en desacord). No obstant això, un futur treball d'anàlisi qualitativa de les programacions de la DC ens podria aportar més informació sobre aquest aspecte.

9. Els programes oferits per la DC són poc innovadors. El 57 \% recolza aquesta afirmació, tot i que és cert que hi ha més suport per part del PAS que del PDI. Aquesta visió divergent del caràcter innovador dels programes crida l'atenció i pot tindre certa relació amb els diferents enfocaments que genera el fet d'ocupar un lloc temporal (PDI) o un lloc permanent (PAS). Sembla que la provisionalitat alleugereix la mirada i la permanència l'endureix.

10. Hi ha escassetat de xarxes acadèmiques i tècniques de coordinació en l'àmbit de la DC. El suport és intens (90\%), per la qual cosa sembla òbvia la necessitat per part de la DC de generar xarxes acadèmiques i tècniques que, potser, augmenten la capacitat d'innovació $\mathrm{i}$ d'actualització.

\section{Les programacions de la DC estan majorità-} riament enfocades a allò artístic. Encara que es confirma majoritàriament (59\%), el percentatge de suport dels enquestats del PDI és similar al percentatge del mateix grup que la rebutja. L'aparició de les denominades UCC+i (Unitat de Cultura Científica i de la Innovació) sembla confirmar aquest element del diagnòstic, ja que no es considera que els vicerectorats $i$ les unitats de la DC siguen els més adequats per a integrar la ciència i la tècnica en les seues programacions. Sens dubte, un fil interessant per al debat.

\section{Les activitats de la DC solen estar allunya-} des / desvinculades de les competències culturals dels estudiants. El $67 \%$ dels enquestats es mostra d'acord amb el divorci de la DC i els seus estudiants. Aquesta realitat necessita ser revertida, però els actuals plans d'estudi, la tipologia de l'estudiantat $i$ els seus horaris ho compliquen. No obstant això, encara que l'allunyament entre la DC i els universitaris és obvi, amb diferents graduacions — de vegades similars-, aquesta separació apareix també en la participació de l'estudiantat en associacions, en activitats esportives, en activitats socials i, per suposat, també en activitats acadèmiques i d'investigació complementàries.

13. Els vicerectorats de la DC s'han adaptat relativament bé - fins i tot millor que altres dimensions de la universitat-a la realitat líquida que ens envolta (xarxes socials, plataformes de vídeo, continguts culturals 3.0, etc.). El $63 \%$ comparteix aquesta afirmació i es confirma com una de les fortaleses de la DC, encara que, potser, més centrada en el tema de comunicació en xarxes socials que en la generació de continguts culturals digitals i media-labs.

14. Els vicerectorats de la DC presenten un problema de marca: la laxitud del terme extensió universitària els ha perjudicat i el vaivé de denominacions dels vicerectorats no ha ajudat gaire a perfilar aquesta marca. El 90 \% dels consultats comparteix aquesta barrera. Des del nostre punt de vista, es tracta més de generar un subsector que de qüestions de marca o màrqueting.

15. El conglomerat de subdimensions que s'integra en els vicerectorats de la DC permet llibertat d'acció i molta presència al territori. Hi ha un acord majoritari (61 \%); seria el revers de la moneda del segon element del diagnòstic: els desposseeix d'uniformitat i coherència missional, però els dota de flexibilitat davant la societat.

16. Les activitats de la DC són jornades de portes obertes permanents per a conéixer la universitat en un entorn no reglat. Pot semblar una obvietat, però té molt d'interés 
i així ho recolza el 69 \% dels enquestats. La veritat és que aquesta oportunitat no sempre ha sigut ben aprofitada pel conjunt de la institució.

17. El paper dels vicerectorats de la DC d'intercanviador entre creadors i productors culturals i els nostres instituts i grups d'investigació està escassament desenvolupat. Queda confirmat majoritàriament (86 \%) i també la necessitat de potenciar, gairebé des de el punt 0 , aquest vector de la programació de la DC, així com compartir les bones pràctiques nacionals i internacionals que es detecten.

18. La imatge positiva de la institució que es projecta des de la DC és un dels punts forts d'aquests vicerectorats. El $92 \%$ ho confirma i, encara que no és específic de la DC sinó més aviat genèric dels serveis i productes culturals, la consideració d'allò cultural com un bé de mèrit es troba darrere d'aquesta imatge positiva i no sotmesa a grans debats (Musgrave, 1968).

19. El professorat que accedeix als càrrecs acadèmics d'aquests vicerectorats té un gran desgast personal que els porta a no repetir mandat; els vicerectorats de la DC són un fre en la carrera acadèmica més que un trampolí. El $47 \%$ dels enquestats ho subscriuen, amb un suport majoritari en el PDI (62 \%). Aquesta visió diferent dels dos col-lectius sobre el mateix aspecte s'arrela en la incapacitat de la universitat espanyola de generar equips de treball supraestamentaris que superen las filiacions laborals a un determinat col-lectiu. En el cas concret de la Universitat de Cadis, amb 40 anys d'història recentment complits el 2019, cap vicerector ni vicerectora de la DC va estar més d'un mandat de quatre anys, i cap d'ells va optar a ser rector posteriorment.

20. El personal tècnic d'aquests vicerectorats té poca mobilitat i escàs reconeixement en l'estructura de la universitat. El seu ascens a càrrecs de gestió o de més responsabilitat, quan es produeix, s'orienta més cap a altres administracions que cap a l'interior de la universitat. El $69 \%$ comparteix aquest element del diagnòstic, encara que amb un percentatge alt de respostes no sap / no contesta en el cas del PDI.

21. La universitat, en general, i els vicerectorats de la dimensió cultural, en particular, exerceixen un lideratge cívic diluiit i escàs. El $63 \%$ percep un feble lideratge cívic que potser és extensible a tota la universitat.

22. La dimensió cultural aspira a ser un agent d'innovació sociocultural en el sentit que assenyala Lester d'espai de debat per als dilemes del futur (Lester i Piore, 2006), però actualment es troba lluny de ser-ho. El 73 \% confirma que no som agents d'innovació sociocultural o creativa, encara que pot ser un bon eix de la nostra nova visió.

23. Des del punt de vista formatiu, la relació amb els professionals de la cultura s'ha basat molt en el grau i el postgrau, però escassament en els títols propis. Aquest element del diagnòstic no es confirma ni es nega, perquè, senzillament, es desconeix (el $47 \%$ no ho sap o no contesta). Sembla que hi ha un desconeixement immens sobre la gestió cultural en els graus, màsters i títols propis entre els gestors de la DC. Aquest desconeixement ens pot fer reflexionar sobre l'escassa importància del nostre paper com a agents culturals a l'interior de la universitat. Per a Bonet, el repte que té la universitat, quant a la formació en matèria de gestió cultural, és el següent:

Formar equips docents compromesos amb el sector professional i el món comunitari, que puguen aconseguir legitimitat pròpia, que compten amb mirada transdisciplinar (intrauniversitària 
i extrauniversitària), de manera que estiguen en condicions de treballar la transversalitat d'allò cultural (...), construir equips que siguen nodes de xarxes i projectes internacionals, que siguen innovadors pedagògicament, que estiguen oberts a les noves generacions i a perfils heterogenis (que sàpiguen donar veu a la diferència), i que, al costat de tot això, puguen estar integrats en la lògica universitària. (Parodi Álvarez, 2017: 32-33)

24. L'orientació formativa dels vicerectorats de la dimensió cultural (cursos d'extensió, cursos d'estiu i escoles) requereix un procés d'actualització en temes i enfocaments pedagògics. El $88 \%$ percep aquesta necessitat peremptòria de nous enfocaments i temes per a un dels programes extensionistes clàssics del nostre país i d'altres països: els cursos d'estiu i/o programes estacionals. A més, els cursos d'extensió que durant molts anys van complementar el currículum competencial dels nostres universitaris mitjançant la borsa de més de vint crèdits de lliure elecció han quedat reduïts a sis crèdits en els últims cursos. Recordem que el terme extensionista en l'àmbit llatinoamericà s'aplica al món rural i s'entén més com els processos que faciliten aprenentatges i intercanvi d'informació, conformació de xarxes de col-laboració i ús de plataformes d'innovació (Landini, 2016).

\section{CONCLUSIONS}

Tots els elements d'aquest autodiagnòstic validat per experts ens porten a una reflexió final sobre si realment disposem d'una política cultural universitària de nivell similar a les polítiques de docència, d'investigació o de transferència amb les quals compten les universitats de l'àmbit europeu. Segons Martinell (Martinell Sempere, 2013), els requisits perquè existisca una política cultural sectorial són aquests:

- Estratègia de difusió cultural (democratització)

- Estratègia de foment i ajuda a la creació
- Estratègia de capacitació cultural que alimente les dues anteriors

- Estratègia de comunicació

En general, pel nostre coneixement del sector de la DC i per tot allò exposat en aquest estudi, confirmem que, en bona part de les universitats públiques espanyoles, es compleixen els quatre requisits esmentats, tot i que la veritat és que, en molts casos, de manera desordenada i poc planificada. Per això, podem afirmar que en l'àmbit espanyol de la DC tenim una política cultural universitària incipient i limitada.

Si tornem a la DC, les principals conclusions sobre la seua situació l'any 2019 són les següents:

1. La DC no s'identifica actualment com una de les missions de la universitat. Durant els anys 90 del segle passat l'extensió universitària era reconeguda com la tercera missió (després de la docència i la investigació). No obstant això, avui en dia la transferència és percebuda per la nostra institució i part de la societat com aquest tercer element missional.

2. La DC no sol aparéixer entre els objectius dels plans estratègics de la universitat i els indicadors culturals no es contemplen en els rànquings, a pesar que les seues activitats són relativament valuoses per a la societat en què s'imbrica.

3. La DC no té una marca definida, perquè la seua missió no està delimitada. Subsisteix entre la històrica extensió universitària i la cada vegada més injuriada responsabilitat social universitària, encara que, com a terme multidimensional, la DC no està integrada en aquests camps de manera adequada. La gran quantitat de subdimensions de contingut i categoria diferents compliquen en excés la seua autodefinició.

4. La DC es desplega en diversos àmbits de la universitat (vicerectorat, centres, departaments, àrees, instituts, grups, etc.), la qual cosa 
l'enriqueix, però també dificulta la construcció d'estratègies i plans.

5. La DC no reuneix grans estructures de suport dins de la institució i, tot i que les que existeixen estan professionalitzades, no formen part de xarxes tècniques de gestió, com és el cas d'altres dimensions de la universitat.

6. La DC protagonitza una part de la vida universitària, però no està en l'agenda de temes de la universitat (consells de govern, claustres i consells socials), per la qual cosa la presència en els òrgans de presa de decisions és testimonial i perifèrica. Malgrat això, paradoxalment, de manera directa o indirecta, la DC està present en quasi la totalitat dels equips de direcció de les universitats.

7. Les programacions de la DC solen estar allunyades de les competències culturals dels estudiants (Morales Sánchez, 2010) i molt bolcades en els continguts artístics i creatius. En aquest àmbit, allò majoritari no és sinònim d'èxit, ni allò minoritari és sinònim de qualitat.

8. La DC té una excel-lent implantació estatal, però no forma part del compendi d'agents que protagonitzen la política cultural estatal (estat, autonomies, ajuntaments, diputacions, indústries culturals, sectors creatius, associacionisme cultural, etc.). La possible creació d'una xarxa formal d'universitats culturals seria més efectiva cap a l'exterior, ja que mostrar el nexe entre més de 70 universitats que fan cultura universitària potser es convertiria en una contrapart d'interés.

9. La DC no lidera l'agenda compartida de les ciutats en què es troba, ni tampoc ocupa un paper de coordinació i integració que seria ben rebut per la societat i els agents culturals.

10. La DC no ha sigut capaç de generar el seu propi sistema d'indicadors normalitzats. Aposten per dissenyar els seus processos d'avaluació amb els seus propis avaluadors (primer per a la comparació, després per a la millora i finalment per al reconeixement).

11. La DC no aborda els espais curriculars i extracurriculars per al PDI (personal docent $\mathrm{i}$ investigador): el PDI rep formació per a millorar en docència i en investigació, però no rep formació sobre la dimensió cultural ni es relacionen les seues activitats amb l'àmbit de la investigació. A més, existeixen estratègies de suport al talent docent $\mathrm{i}$ investigador, però poc s'ha avançat en la captació de talent cultural des de la universitat.

12. La DC, com la mateixa universitat, no exerceix un lideratge cívic i tampoc ha aconseguit ser un agent privilegiat d'innovació sociocultural.

CODA

El juliol de 2018, en el seminari Cultura en / des de / per a la Universitat (2018) vam dur a terme un joc —entre personal i literari- en què, partint del títol del seminari es desplegava un sistema complet de relacions entre els termes cultura i universitat, segons canviava la preposició que les unia. El presentem a continuació, perquè considerem que pot ser una manera oportuna de plantejar alguns reptes per al futur en relació amb la dimensió cultural de la universitat espanyola:

Cultura a la universitat. El viatge que encara no fan algunes institucions culturals per adaptar-se a la realitat universitària.

Cultura davant la universitat. La cultura digital i/o col-laborativa que cada dia més tenim davant i no volem veure.

Cultura sota la universitat. La que es juga sota les rígides estructures oficials i que no som capaços de detectar.

Cultura amb la universitat. La que busquen molts creadors i gestors a les nostres ciutats i territoris. 
Cultura contra la universitat. La que ens trobem de vegades per part d'altres agents culturals externs.

Cultura de la universitat. La cultura encara per definir i construir que donarà sentit a la nostra missió.

Cultura des de la universitat. La cultura unidireccional que heretem dels extensionistes.

Cultura en la universitat. La cultura que sorgeix i creix als nostres campus (promoció).

Cultura entre la universitat i la societat. A la qual hauríem de tendir cada vegada més.

Cultura cap a la universitat. La gestió cultural que emergeix, però que no acaba d'arribar.

Cultura fins a la universitat. La que ens limita geogràficament en l'àmbit dels nostres campus.

Cultura per a la universitat. La que encara no som capaços de definir i desenvolupar de manera eficient.
Cultura per la universitat. La que sostenim de manera voluntarista i missional una gran part de les persones que ens trobem ací.

Cultura segons la universitat. La cultura oficial que es transmet d'una manera o d'una altra des dels vicerectorats de la dimensió cultural.

Cultura sense la universitat. La que té lloc en moltes ciutats espanyoles amb campus universitari.

Cultura sobre la universitat. La que ens convertiria en subjectes de la investigació cultural.

Cultura després de la universitat. La que no acabem d'encaixar en els processos de docència i investigació.

Cultura durant la universitat. La que podríem incrementar entre els nostres estudiants durant el seu pas.

Cultura mitjançant la universitat. La que podríem generar amb processos d'investigació i innovació en el nostre teixit sociocultural.

\section{REFERÈNCIES BIBLIOGRÀFIQUES}

Ariño Villarroya, A. (2007). Cambio de paradigma en la función cultural de la Universidad. En M. Cantos Casenave i A. J. González Rueda (coord), Monografía. La extensión universitaria que viene: Estudio prospectivo de escenarios ideales (p.15-44). Cadis: Servicio de Publicaciones de la Universidad de Cádiz. Recuperat de https://dialnet. unirioja.es/servlet/articulo?codigo $=2555891$

Ariño Villarroya, A. (2016). 3.1.1 Gestión cultural universitaria. En L. Ben Andrés, V. Rivas Serrano i C. Ojeda Gómez (ed.), Manual Atalaya de apoyo a la gestión cultural. Cadis: Universidad de Cádiz. Recuperat de http:// atalayagestioncultural.es/capitulo/gestion-cultural-universitaria

Ariño Villarroya, A. i González Rueda, A. J. (2012). La dimensión cultural de la universidad en el estado español. Periférica Internacional. Revista para el análisis de la cultura y el territorio, 13. Recuperat de https://revistas.uca.es/ index.php/periferica/article/view/1864

Cantero, C. (2006). El concepto de la extensión universitaria a los largo de la historia. Cadis: Dirección General de Universidades de la Consejería de Innovación, Ciencia y Empresa de la Junta de Andalucía. Recuperat de https:// cercles.diba.cat/cgi-bin/koha/opac-detail.pl?biblionumber $=43548$

Cedeño Ferrín, J. (2012). Tendencias del proceso de gestión de la Extensión Universitaria y su impacto cultural. Rev Humanidades Médicas, 12(3), 499-514. Recuperat de: http://www.humanidadesmedicas.sld.cu/index.php/hm/ article/view/247/165http://scieloprueba 
Coronas, S. M. (2005). Altamira: De la cátedra de Historia del Derecho a la Historia de las Instituciones Políticas y Civiles de América. Alacant: Biblioteca Virtual Miguel de Cervantes. Recuperat de http://www.cervantesvirtual.com/ obra-visor/altamira---de-la-ctedra-de-historia-del-derecho-a-la-historia-de-las-instituciones-polticas-y-civilesde-amrica-0/html/0046743e-82b2-11df-acc7-002185ce6064_15.html

Draper, W. H. (1923). University Extension: A Survey of Fifty Years (1873-1923). Londres: The University Press. Recuperat de https://archive.org/details/universityextens013150mbp/page/n29

Encyclopedia Britannica. (n.d.). University extension. Recuperat el 6 d'abril de 2019 de https://www.britannica. com/topic/university-extension

Freire, P. (1973). ¿Extensión o comunicación? La concientización en el medio rural. Mèxic: Siglo XXI Editores.

García Guatas, M. (2004). Orígenes y circunstancias de la extensión universitaria en España. Alacant: Biblioteca Virtual Miguel de Cervantes. Recuperat de http://www.cervantesvirtual.com/obra/orgenes-y-circunstancias-de-laextensin-universitaria-en-espaa-0/

García, T. (4 d’abril de 2019). Conferencia de Jaron Rowan en la UCA: ¿Cultivarse o ser cultivado? Diario de Cádiz. Recuperat de https://www.diariodecadiz.es/ocio/conferencia-Jaron-Rowan-UCA_0_1342366337.html

González Rueda, A. J. (2004). 25 años de extensión universitaria en la provincia de Cádiz. En V. Atero Burgos i A. J. González Rueda, Universidad de Cádiz. 25 años (p. 179-206). Cadis: Servicio de Publicaciones de la Universidad de Cádiz. Recuperat de https://extension.uca.es/wp-content/uploads/2017/10/2708.pdf?u

González Rueda, A. J. (2017). La dimensión cultural de la universidad en el estado español. [Vídeo]. Recuperat de https:// www.youtube.com/watch?v=aqJhQR13k2c

Landini, F. (2016). Problemas de la extensión rural en América Latina. Perfiles Latinoamericanos, 24(47), 47-68. DOI: $10.18504 / \mathrm{pl} 2447-005-2016$

Lester, R. K. i Piore, M. J. (2006). Innovation: The Hidden Dimension. Harvard: Harvard University Press.

Llei orgànica 11/1983, de 25 d'agost, de reforma universitària, BOE 209, de 24.034 a 24.042 (1983). Recuperat de http://www.dogv.gva.es/datos/2002/04/24/pdf/2002_A3538.pdf

Llei orgànica 4/2007, de 12 d'abril, pel qual es modifica la Llei orgànica 6/2001, de 21 de desembre, d'universitats . BOE 89, de 2.063 a 2.082 (2007). Recuperat de https://www.boe.es/boe_catalan/dias/2007/04/16/pdfs/A0206302082.pdf

Martinell Sempere, A. (2013). 3.4 Modelos de gestión. En L. Ben Andrés, V. Rivas Serrano i C. Ojeda Gómez (ed.), Manual Atalaya de apoyo a la gestión cultural. Cádiz: Universidad de Cádiz. Recuperat de http://atalayagestioncultural. es/capitulo/modelos-gestion

Mejía Arango, J. L. (2018). La dimensión cultural de la universidad. [Vídeo]. Recuperat de https://www.youtube.com/ watch?v=CLD9JGFVjYQ

Melón Fernández, S. (1987). La extensión universitaria-antecedentes y características. En Clarín y La Regenta en su tiempo: actas del Simposio Internacional. (p. 93-184). Oviedo: Universidad de Oviedo, Servicio de Publicaciones. Recuperat de https://dialnet.unirioja.es/servlet/articulo?codigo=903718

Melón Fernández, S., Álvarez Antuña, V., Friera Suárez, F. i Ruiz de la Peña, A. (2002). Santiago Melón Fernández. Obra completa. Oviedo: Servicio de Publicaciones de la Universidad de Oviedo. Recuperat de https://publicaciones. uniovi.es/catalogo/publicaciones/-/asset_publisher/pW5r/content/obra-completa-de-santiago-melon-fernand ez;jsessionid=CAC07B6C31604A22AAC2ECEAB2D2C1D0?redirect=\%252Fcatalogo\%252Fpublicaciones $\% 253$ Fp_p_id\%253D101_INSTANCE_pW5r\%2526p_p_lifecycle\%253

Morales Sánchez, M. I. (ed.) (2010). Dossier de trabajo: Competencias culturales de los universitarios. Cadis: Junta de Andalucía. Recuperat de http://www.observatorioatalaya.es/wp-content/uploads/2018/02/CompetenciasCulturales-de-los-Universitarios.pdf

Musgrave, R. A. (1968). The Theory of Public Finance. Madrid: Aguilar.

Palacios Morini, L. (1908). La extensión universitaria. En L. Palacios Morini, Las universidades populares (p. 125-156). València: F. Sempere y Compañía Editores. Recuperat de http://www.filosofia.org/aut/lpm/lup10.htm

Parodi Álvarez, M. J. (2017). Universidad y cultura: balance de una relación. Relato del seminario de verano del Observatorio Cultural del Proyecto Atalaya. Periférica Internacional. Revista para el análisis de la cultura y el territorio, 18. Recuperat de https://revistas.uca.es/index.php/periferica/article/view/4173

Penelas, S. (30 d'abril de 2013). La dimensión cultural de la Universidad rompe fronteras. El Faro de Vigo. Recuperat de https://www.farodevigo.es/gran-vigo/2013/04/30/dimension-cultural-universidad-rompe-fronteras/800678.html 
Ramoneda, J. (2013). XI tesis sobre la cultura. La Maleta de Portbou. Revista de humanidades y economía, 1. Recuperat de https://lamaletadeportbou.com/articulos/xi-tesis-sobre-la-cultura/

Red Telescopi. Buena práctica: Observatorio cultural del Proyecto Atalaya. Recuperat el 6 d'abril de 2019 de https:// telescopi.upc.edu/detalle-de-buenas-practicas?numero=315

Red Telescopi. Repositorio de Buenas Prácticas. Recuperat el 6 d'abril de 2019 de https://telescopi.upc.edu/buenaspracticas/buscar-buenas-practicas?page $=$ index \& tipo $=\&$ area $=5 \&$ pais $=8 \&$ filtrar=Filtrar

Ruiz Corbella, M. y Bautista-Cerro Ruiz, M. J. (2016). La responsabilidad social en la universidad española = University's social responsibility at Spanish universities = Responsabilité sociale dans l'université espagnole, 28, 159-188. https://doi.org/10.14201/teoredu2016281159188

Solicitud de creación de la comisión sectorial de extensión universitaria en el seno de la CRUE (2003). Recuperat el 6 d'abril de 2019 de http://www.cervantesvirtual.com/obra-visor/solicitud-de-creacin-de-la-comisin-sectorialde-extensin-universitaria-en-el-seno-de-la-crue-0/html/0046c2e0-82b2-11df-acc7-002185ce6064_2.html

Welch, E. (1973). The Peripatetic University: Cambridge Local Lectures, 1873-1973. Cambridge: Cambridge University Press.

\section{NOTA BIOGRÀFICA}

\section{Antonio Javier González Rueda}

Llicenciat en Història, diplomat universitari en Biblioteconomia i Documentació per la Universidad de Granada, expert universitari en Programes de Gestió Cultural i doctor en Arts i Humanitats per la Universidad de Cádiz. És gestor cultural de la Universidad de Cádiz, on també investiga en l'INDESS. És especialista en fenòmens de patrimonialització.

\section{Antonio Ariño Villarroya}

Catedràtic de Sociologia en la Universitat de València. Investiga sobre sociologia de la cultura i teoria sociològica. Entre les seues publicacions més recents es troben Culturas abiertas, Culturas Críticas (Tirant lo Blanch, 2019) i Cultura Universitaria. Políticas para la Alma Mater (Tirant lo Blanch, 2020). 